\title{
Pengaruh Kualitas Layanan (Service Quality) Terhadap Kepuasan Pelanggan (Customer Satisfaction) (Survey Pelanggan Jasa Transportasi Grab Car di Kampus UBD Tangerang)
}

\author{
Yosamanta Vistara1) \\ Petrus T. Resi2) \\ Manajemen, Universitas Buddhi Dharma, Banten, Indonesia
}

\begin{abstract}
Abstrak
Penelitian ini dilatarbelakangi oleh pemikiran bahwa pesatnya teknoogi informasi menyebabkan bisnis baik produk barang maupun jasa mengalami pergeseran kedalam bisnis online, tidak terkecuali bisnis jasa dalam bidang tranportasi atau angkutan umum. Adapun tujuan penelitian adalah untuk mengetahui pengaruh kualitas pelayanan (service quality) jasa transportasi online Grab Car terhadap Kepuasan Pelanggan (customer satisdaction) di Kampus UBD Tangerang dilihat dari persepsi pelanggan. Populasi penelitian adalah seluruh mahasiswa Universitas Buddhi Dharma Tangerang pengguna jasa Grab Car. Sampel diambil berdasarkan purposive sampling sebanyak 50 responden.

Hasil analisis terhadap data penelitian secara umum, kualitas pelayanan jasa transportasi online Grab Car di Kampus UBD Tangerang dalam kategori baik dan Secara umum, kepuasan pelanggan jasa transportasi online Grab Car di Kampus UBD Tangerang dalam kategori baik. Korelasi antara kualitas pelayanan dengan kepuasan pelanggan jasa transportasi online Grab Car di Kampus UBD Tangerang dalam kategori signifikan, ditunjukkan oleh nilai koedisien korelasi sebesar 0,848.

Uji Hipotesis menunjukkan meolak $\mathrm{H}_{0}$ yang menyatakan tidak terdapat pengaruh positif dan signifikan antara kualitas pelayanan terhadap kepuasan pelanggan jasa transportasi online Grab Car di Kampus UBD Tangerang, atau dengan kata lain menerima $\mathrm{H}_{1}$ yang menyatakan terdapat pengaruh positif dan signifikan antara kualitas pelayanan terhadap kepuasan pelanggan jasa transportasi online Grab Car di Kampus UBD Tangerang.
\end{abstract}

Kata Kunci: Kualitas Layanan; Kepuasan. 


\begin{abstract}
This research is motivated by the idea that the rapid information technology causes businesses in both goods and services to experience a shift into online business, including service businesses in the field of transportation or public transportation. The purpose of the study was to determine the effect of service quality on Grab Car's online transportation services on customer satisfaction at the UBD Tangerang Campus as seen from the customer's perception. The study population was all students of the University of Buddhi Dharma Tangerang, Grab Car service users. The sample was taken based on purposive sampling as amount 50 respondent.

The results of the analysis of the research data in general, the quality of Grab Car's online transportation services at UBD Tangerang Campus is in good category. In general, customer satisfaction at Grab Car's online transportation services at UBD Tangerang Campus is in good category. Correlation between service quality and customer satisfaction Grab Car online transportation services at UBD Tangerang Campus are in a significant category. This is indicated by the coefficient of correlation 0.848 (strong correlation).

The effect of service quality on customer satisfaction Grab Car online transportation services at UBD Tangerang Campus is in a significant category. This can be seen from the determination index of 0.713 , which means $71.3 \%$ of service quality affects customer satisfaction, the rest is determined by other factors.

Hypothesis test shows reject $\mathrm{HO}$ which states that there is no positive and significant influence between service quality on customer satisfaction Grab Car online transportation services at UBD Tangerang Campus, or in other words accept H1 which states there is a positive and significant influence between service quality on customer service transportation satisfaction Grab Car online at the UBD Tangerang Campus.
\end{abstract}

Keyword: Service Quality; Satisfaction

\title{
PENDAHULUAN
}

Penerapan teknologi dan informasi menyebabkan perubahan dalam kebiasaan atau habit yang baru pada bidang bisnis. Seperti pemanfaatan media perdagangan perusahaan jasa menggunakan media internet yang saat ini tidak sulit dijangkau oleh semua kalangan. Dampak utama dalam penggunaan teknologi informasi dan komunikasi dalam bisnis adalah tingginya volume penggunaan internet.

Konsumen, selalu mengharapkan pelayanan yang baik dalam usaha memenuhi kebutuhan dan keinginannya, dengan berkembangnya ekonomi, teknologi dan daya pikir, konsumen menyadari bahwa dirinya mempunyai hak untuk mendapatkan pelayanan yang baik serta biaya yang dikeluarkan untuk memenuhi kebutuhan dan keinginan harus sesuai dengan yang diharapkan, sehingga dalam rangka pemenuhan kebutuhan dan keinginan tersebut harus diiringi oleh tingkat kepuasan.

Produk Jasa harus dapat memuaskan keinginan dan kebutuhan konsumen tersebut karena yang ditawarkan pada dasarnya tidak berwujud dan tidak menghasilkan kepemilikkan apapun. Kegiatan jasa tidaklah terlepas dari produsen dan konsumen itu sendiri, jasa yang diberikan oleh produsen kepada konsumen 
akan bermanfaat apabila jasa yang diberikan dapat sampai kepada konsumen untuk memenuhi kebutuhannya.

Banyak faktor yang mempengaruhi kepuasan pelanggan salah satunya adalah faktor harga. Harga merupakan aspek penting, namun yang lebih penting adalah kualitas pelayanan guna mencapai kepuasan konsumen. Meskipun demikian elemen ini mempengaruhi konsumen dari segi biaya yang dikeluarkan, biasanya semakin mahal biaya maka konsumen mempunyai harapan yang lebih besar.

Kehadiran jasa transportasi berbasis aplikasi online yang menggunakan internet sangat berpengaruh bagi masyarakat dalam segala aktifitas secara cepat dan efisien. Salah satu perusahaan transport online yang ada di Indonesia yaitu Grab. Cara kerja Grab yaitu menggunakan aplikasi yang terhubung dengan internet. Para pelanggan melakukan pemesanan melalui aplikasi internet sesuai kebutuhan. Tarif transportasi akan langsung ditampilkan di aplikasi saat nelakukan pemesanan. Dengan pelanggan akan lebih mudah dan tahu berapa biaya yang harus disiapkan sehingga pengguna dapat mengambil keputusan akan meneruskan panggilan atau membatalkannya. Perusahaan yang menyediakan transportasi berbasis online tersebut memberikan pelayanan utama yaitu kendaraan roda dua dan roda empat sesuai jenis produk yang ditawarkan.

Fenomena kualitas layanan menjadi tujuan dalam memperbaiki pemenuhan kepuasan konsumen atas pelayanan yang diterima yaitu terpenuhinya harapan, keinginan dan kebutuhan konsumen. Harapan konsumen yaitu cepat mendapatkan pelayanan, keinginan konsumen yaitu pelayanan sesuai dengan jangkauan pembiayaan yang dikenakan, dan kebutuhan konsumen yaitu terpenuhinya layanan yang berkualitas.

\section{LANDASAN TEORI Kepuasan Pelanggan}

Pelanggan merupakan fokus utama dalam pembahasan mengenai kepuasan dan kualitas jasa, karena ukuran yang diberikan mengenai kualitas jasa ditentukan oleh pelanggan. ISO 9000:2000 menyebutkan bahwa “... organisasi bergantung kepada pelanggannya dan hendaknya memahami kebutuhan saat ini dan masa depan pelanggannya". Selanjutnya ditentukan juga persyaratan pemenuhan kepuasan pelanggan yaitu “... perusahaan hendaknya memenuhi dan berusaha melampaui harapan pelanggan".

Seluruh kegiatan yang dilakukan oleh sebuah perusahaan pada akhirnya bermuara pada nilai yang akan diberikan oleh pelanggan terhadap perusahaan tersebut mengenai kepuasan yang duirasakan oleh pelanggan. Kepuasan merupakan tingkat perasaan seseorang yang dinyatakan dari hasil perbandingan atas kinerja produk jasa yang diterima dengan yang diharapkan (Kotler, 1997 dalam Lupiyoadi, 2016:246).

Kepuasan (satisfaction) berasal dari bahasa Latin "satis" (cukup baik, memadai) dan "facio" (melakukan, membuat). Dalam pengertian yang sederhana, kepuasan diartikan sebagai usaha pemenuhan sesuatu atau membuat sesuatu menjadi memadai, tetapi dalam perspektif pelanggan, kepuasan menjadi hal yang cukup kompleks, bahkan sampai saat ini belum dicapai kesepakan yang sempurna 
mengenai konsep kepuasan dilihat dari banyaknya definisi yang dikemukakan para pakar.

Dari beberapa pendapat mengenai kepuasan, Kotler dan Keller (2012) sebagai salahsatu pakar pemasaran mengemukakan bahwa kepuasan pelanggan adalah tingkat perasaan seseorang setelah membandingkan kinerja (atau hasil) yang ia rasakan dibandingkan dengan harapannya. Akan tetapi dari beberapa studi literatur menunjukkan bahwa salahsatu definisi yang paling banyak diacu dalam literatur pemasaran adalah definisi berdasarkan disconfirmation paradigm (Oliver, 997 dalam Tjiptono, 2017:354).

Ketidakpuasan dapat menimbulkan sikap negatif terhadap merk maupun penyedia jasanya atau bisa juga distributornya bahkan terhadap pelaku ditingkat yang paling bawah yang berhubungan dengan konsumen secara langsung, berkurangnya pembelian atau penggunaan ulang prouk atau jasa yang ditawarkan, peralihan merk atau jasa layanan (brand switching) atau perilaku komplain lainnya.

\section{Pengukuran Kepuasan Pelanggan}

Meskipun belum ada konsesnsus mengenai cara mengukur kepuasan pelanggan, sejumlah penelitian menunjukkan terdapat tiga aspek penting yang perlu dikaji dalam mengukur kepuasan pelanggan (Fornel et al, 2005 dalam Tjiptono, 2017:368) yaitu:

1) Kepuasan general atau keseluruhan (overall satisfaction)

2) Konfirmasi harapan (confirmation of expectation)

3) Perbandingan dengan situasi ideal (comparison to ideal)

Tidak ada satupun ukuran tunggal yang paling baik mengenai kepuasan pelanggan secara universal, akan tetapi paling tidak terdapat enam konsep inti mengenai objek pengukuran, yaitu:

1) Kepuasan pelanggan secara kseluruhan (overall customer satisfaction); cara yang paling sederhana adalah bertanya kepada pelanggan, seberapa puas terhadap jasa yang telah digunakan, pertama: mengukur tingkat kepuasan pelanggan terhadap barang atau jasa perusahaan bersangkutan, kedua: menilai dan membandingkannya dengan tingkat kepuasan pelanggan secara keseluruhan terhadap barang atau jasa para pesaing.

2) Dimensi kepuasan pelanggan; umumnya terdiri atas empat langkah. Pertama: mengidentifikasi dimensi-dimensi kunci kepuasan pelanggan. Kedua: meminta pelanggan menilai produk pesaing berdasarkan item spesifik seperti kecepatan layanan, fasilitas, keramahan staf layanan pelanggan dan sebagainya. Ketiga: meminta pelanggan menilai produk pesaing berdasrkan item spesifik yang sama. Keempat: meminta pelanggan menentukan dimensi-dimensi yang menurutnya paling penting dalam menilai kepuasan pelanggan secara keseluruhan.

3) Konfirmasi harapan (confirmation of expectation); kepuasan diukur langsung, namun disimpulkan berdasarkan kesesuaian/ ketidaksesuaian antara harapan pelanggan dengan kinerja aktual produk perusahaan pada sejumlah aspek atau dimensi penting.

4) Nilai beli ulang (repurchase intention); kepuasan pelanggan diukur secara behavioral dengan menanyakan kepada pelanggan apakah akan menggunakan produk lagi. 
5) Kesediaan untuk merekomendasi (willingness to recommend); kesediaan pelanggan untuk memberitahukan kepada yang lainnya (teman/ keluarga) untuk menggunakan produk. Kesediaan pelanggan untuk merekomendasikan ini menjadi hal yang penting untuk ditindaklanjuti.

6) Ketidakpuasan pelanggan (customer dissatisfaction); beberapa aspek yang sering ditelaah adalah komplain, retur, biaya garansi, product recall, gethok tular negatif dan defections (konsumen yang beralih ke pesaing).

\section{Skala Pengukuran Kepuasan Pelanggan}

Untuk skala pengukuran penelitian, biasanya digunakan Skala Liker 4 skala 1 = sangat tidak puas, $2=$ tidak puas, $3=$ puas, $4=$ sangat puas; atau skala Likert 5 pilihan (Poin) yaitu 1 = Sangat Tidak memaskan, $2=$ Tidak Memuaskan, $3=$ Netral, $4=$ Memuaskan dan 5 = Sangat memuaskan. Nilai-nilai tersebut berlaku apabila pernyataan bersifat positif, dan untuk pernyataan negatif berlaku sebaliknya.

\section{Kualitas Jasa}

Nilai yang diberikan pelanggan sangat kuat didasari oleh faktor kualitas jasa yang diberikan, karena kualitas produk (jasa) adalah sejauh mana produk (jasa) tersebut memenuhi spesifikasinya. Menurut ISO 9000, kualitas adalah "degree to which a set of inherent characteristic fulfil requirements" (derajat yang dicapai oleh karakteristik yang inheren dalam memenuhi persyaratan". Persyaratan dalam hal ini adalah "kebutuhan atau harapan yang yang dinyatakan, biasanya tersirat atau wajib" (Lupyoadi, 2016:230).

Jadi kualitas sebagaimana tersebut di atas adalah merupakan perpaduan antara sifat dan karakteristik yang menentukan sejauhmana outputnya dapat memenuhi persyaratan kebutuhan pelanggan, dan pelangganlah yang menentukan dan menilai seberapa jauh sifat dan karakteristik tersebut memenuhikebutuhannya.

\section{Dimensi Kualitas Jasa}

Parasuraman, dkk (1998) dalam Lupiyoadi (2017:234-235) menge-mukakan 5 dimensi kualitas yaitu:

1) Berwujud (tangible), yaitu kemampuan suatu perusahaan dalam menunjukkan eksistensinya kepada pihak eksternal. Penampilan dan kemampuan sarana dan prasarana yang dapat diandalkan keadaan lingkungan sekitarnya merupakan bukti nyata dari pelayanan yang diberikan oleh pemberi jasa, meliputi fasilitas fisik, perlengkapan dan peralatan yang digunakan (teknologi), serta penampilan pegawainya.

2) Reliabilitas (reliability), yaitu kemampuan perusahaan untuk memberikan pelayanan sesuai dengan yang dijanjikan secara akurat dan terpercaya. Kinerja harus sesuai dengan harapan pelanggan yang berarti ketepatan waktu, pelayanan yang sama untuk semua pelanggan tanpa kesalahan, sikap yang simpatik, dan dengan akurasi yang tinggi.

3) Ketanggapan (responsiveness), yaitu suatu kebijakan untuk membantu dan memberikan pelayanan yang cepat (responsif) dan tepat kepada pelanggan, dengan penyampaian informasi yang jelas. Membiarkan pelanggan menunggu menciptakan persepsi yang negatif dalam kualitas pelayanan.

4) Jaminan dan kepastian (assurance), yaitu pengetahuan, kesopanan, dan kemampuan pegawai perusahaan untuk menumbuhkan rasa percaya para 
pelanggan kepada perusahaan. Hal mi meliputi beberapa komponen antara lain komunikasi (communication), kredibilitas (credibility), keamanan (security), kompetensi (competence), dan sopan santun (courtesy).

5) Empati (empathy), yaitu memberikan perhatian yang talus dan bersifat pribadi yang diberikan kepada para pelanggan dengan berupaya memahami keinginan mereka. Harapannya adalah bahwa suatu perusahaan memiliki pengertian dan pengetahuan tentang pelanggan, memahami kebutuhan pelanggan secara spesifik, serta memiliki waktu pengoperasian yang nyaman bagi pelanggan.

\section{Skala Pengukuran ServQual}

Untuk memungkinkan para pelanggan menjawab dalam berbagai tingkatan bagi setiap butir kepuasan, format jenis likert bisa digunakan. R.A. Likert (1932) mengembangkan prosedur penskalaan di mana skala mewakili suatu kontinum bipolar. Ujung sebelah kin (dengan angka rendah) menggambarkan suatu jawaban yang negatif, sedangkan ujung kanan (dengan angka tinggi) menggambarkan yang positif. Kategori yang digunakan oleh skala likert berupa analisis tingkat kepentingan dan kinerja dengan lima kategori berikut (Supranto, 1997 dalam Lupiyoadi, 2017:236): 1) Sangat penting/sangat puas $=5$; Penting $/$ puas $=4 ;$ Netral $=$ 3 ; Tidak penting/tidak puas $=2$; Sangat tidak penting $/$ sangat tidak puas $=1$.

\section{METODE PENELITIAN}

\section{a. Populasi dan Samel}

Populasi keseluruhan dalam penelitian ini adalah seluruh mahasiswa UBD Tangerang pengguna jasa transportasi online Grab Car. Mengingat jumlah populasi dalam penelitian ini tidak diketahui secara pasti, maka penulis mengambil satu ketetapan bahwa sampel diambil berdasarkan tujuan tertentu (purposive) yaitu responden yang telah menggunakan jasa transportasi online Grab Car yang ditentukan berjumlah 50 orang. Teknik ini dianggap paling baik untuk kasus penelitian ini terletak pada teori yang mendasarinya juga pada bukti-bukti empiris.

\section{b. Metode Penelitian}

Jenis penelitian yang digunakan adalah kuantitatif, Menurut Juliansyah Juliansyah Noor (2013;38) penelitian kuantitatif merupakan metode penelitian untuk menguji teori-teori tertentu dengan cara meneliti hubungan antar variabel. Jadi penelitian kuantitatif adalah penelitian yang mendasarkan pada perhitungan data angka atau statistik dalam mengambil kesimpulan.

\section{c. Variabel Penelitian}

Definisi Konseptual Kepuasan Pelanggan; Kepuasan pelanggan merupakan suatu tindakan dimana kebutuhan, keinginan, dan harapan dari pelanggan dapat terpenuhi yang akan mengakibatkan adanyan, pembelian ulang atau kesetiaan yang berlanjut (Band, 1991) dalam Musanto (2004:123-136). Definisi Oprasional Kepuasan Pelanggan; adalah skor kumulatif data yang diperoleh dari jawaban responden terhadap pernyataan kuesioner yang telah dikuantifikasi. Indikator Kepuasan Pelanggan; 1) Keengganan untuk berpindah ke perusahaan lain, 2) Penggunaan berkelanjutan, 3) Merekomendasikan kepada orang lain.

Definisi Konseptual Kualitas Pelayanan (Service Quality): Kualitas pelayanan merupakan ukuran seberapa baik tingkat layanan yang diberikan sesuai harapan pelanggan (Lewis dan Booms (1983) dalam Parasuraman et. al., 1985:41-50). Definisi 
Oprasional Kualitas pelayanan adalah skor kumulatif data yang diperoleh dari jawaban responden terhadap pernyataan kuesioner mengenai kualitas pelayanan yang telah dikuantifikasi. Indikator Kualitas Layanan meliputi dimensi 1)Tangible (X1) meliputi kelengakapan fasilitas pelayanan, Tampilan fisik perusahaan, dan kebersihan tempat pelayanan; 2) Reliability (X2) terdiri dari ketepatan pelayanan dan kesesuaian pelaksanaan pelayanan. 3) Responsiveness (X3) terdiri dari tingkat daya tanggap karyawan dan kecepatan pelayanan. 4) Assurance (X4) terdiri dari adanya jaminan, dan adanya kepercayaan pelanggan; 5) Emphaty (X5) terdiri dari keramahan dan kecakapan karyawan, dan perhatian terhadap pelanggan

\section{d. Teknik Pengumpulan Data}

Pengumpulan data penelitian dilakukan mengunakan kuesioner (instrumen penelitian) terhadap responden. Jenis instrument yang digunakan dalam penelitian adalah instrument tertutup menggunakan Skala Likert 4 alternatif jawaban. Skala Likert digunakan untuk mengukur pendapat dan persepsi seseorang atau kelompok orang tentang fenomena atau gejala sosial yang terjadi (Iskandar, 2009;82).

Untuk mendapatkan hasil data yang sahih, maka instrumen penelitian dilakukan ujicoba, hasil ujicoba instrumen dihitung menggunakan statistik untuk mengetahui validitas dan reliabilitasnya.

\section{e. Teknik Analisis Data}

1) Analisis Deskripsi

Analisis deskriptif adalah statistik yang digunakan untuk menganalisa data dengan cara mendeskripsikan atau menggambarkan data yang telah terkumpul sebagaimana adanya tanpa bermaksud membuat kesimpulan yang berlaku untuk umum atau generalisasi (Sugiyono, 2017:206). Setelah data terkumpul maka langkah selanjtnya yaitu mengolah data, kemudian mendistribusikannya ke dalam table kemudian membahas data tersebut secara deskriptif.

2) Analisis Korelasi

Korelasi merupakan teknik statistik yang digunakan untuk menguji ada tidaknya hubungan serta arah hubungan dari dua variabel atau lebih. Besar kecilnya hubungn antara variabel dinyatakan dalam bilangan yang disebut Koefisien Korelasi. Besaran Koefisien Korelasi antara -1 dan 1. Besaran korelasi -1 dan 1 adalah korelasi yang sempurna. Koefisiien Korelasi 0 atau mendekati 0 baik dari sisi kiri (-) maupun sisi kanan (+) dianggap tidak mempunyai hubungan.

3) Analisis Regresi

Analisis Regresi Linier Berganda Analisis regresi linier berganda dalam penelitian melakukan pengujian secara berganda (Uji F) dan pengujian secara parsial (Uji t). Pada Uji F kriteria uji yang digunakan adalah jika nilai signifikansi $(\mathrm{F}) \mathrm{a}=0,05$ maka $\mathrm{H}_{0}$ diterima dan $\mathrm{H}_{1}$ ditolak. Pada Uji t penentuan nilai statistic table, ditentukan dengan tingkat signifikansi 5\%.

4) Uji Hipotesis

Uji hipotesis data dalam penelitian ini dimaksudkan untuk menguji hipotesis yang dikemukakan. Sesuai dengan permasalahan dan hipotesis penelitian maka analisis data yang relevan untuk maksud ini adalah analisis korelasi. Pengujian dilakukan terhadap hipotesis statistik, a) jika t hitung lebih besar dari tabel maka H0 
ditolak dan Ha diterima; b) jika thitung kurang dari $\mathrm{t}$ tabel maka H0 diterima dan Ha ditolak.

\section{HASIL dan PEMBAHASAN}

\section{a. Analisis Deskriptif}

1) Jumlah responden sebanyak 50, nilai rata-rata (mean) data dari variabel kualitas pelayanan $(X)$ sebesar 81,10 dengan standar deviasi sebesar 11,195.

2) Jumlah responden sebanyak 50, nilai rata-rata (mean) data dari variabel kepuasan pelanggan (Y) sebesar 21,86 dengan standar deviasi sebesar 3,742.

\section{b. Analisis Korelasi}

Koefisien korelasi antara variabel kualitas layanan dengan kepuasan pelanggan sebesar 0,848 pada $\mathrm{df}=49$. Koefisien korelasi 0,848 berada pada kisaran kriteria korelasi signifikan. Nilai signifikansi juga dapat dilihat dari nilai Sig. (2 tiled), 0,000 < 0,005 Jadi dapat dikatakan bahwa antara variabel kualitas pelayanan dengan variabel kepuasan pelanggan mempunyai hubungan yang signifikan dengan arah positif.

Mengingat dimensi kualitas pelayanan terdiri dari 5 (lima) yaitu Tangible, Rwliability, Resposiveness, Assurance dan Emphaty, kadang ingin diketahui dimensi mana yang paling memberikan pengaruh atau paling tidak yang berkorelasi paling tinggi dengan kepuasan pelangga, Untuk masalah ini, dikemukakan data korelasi antara dimensi-dimensi kualitas pelayanan sebagai berikut:

Berdasarkan tabel korelasi antara dimensi-dimensi kualitas layanan terhadap keluasan terlihat bahwa koefisien korelasi (r) Tangible dengan kepuasan sebesar 0,67, koefisien korelasi (r) Rekiability dengan kepuasan sebesar 0,72, koefisien korelasi (r) Responsiveness dengan kepuasan sebesar 0,57, koefisien korelasi (r) Assurance dengan kepuasan sebesar 0,836 dan koefisien korelasi antara Emhaty dengan kepuasan sebesar 0,841. Denga demikian terilhat bahwa korelasi yang palin tinggi terdapat pada dimensi Assurance dengan kepuasan pelanggan.

\section{c. Analisis Regresi}

Variables Entered/Removed ${ }^{a}$

\begin{tabular}{|l|l|c|l|}
\hline Model & \multicolumn{1}{|c|}{ Variables Entered } & Variables Removed & Method \\
\hline 1 & Kualitas Pelayanan & & Enter \\
\hline
\end{tabular}

a. All requested variables entered

b. Dependent Variable: Kepuasan Pelanggan

Metode yang digunakan untuk menganalisis regresi pada penelitian ini adalah metode Enter dengan cara memasukkan seluruh variabel yang akan dianalis.

Model Summary ${ }^{b}$

\begin{tabular}{|c|c|c|c|c|c|c|c|c|c|}
\hline \multirow[b]{2}{*}{ Model } & \multirow[b]{2}{*}{$\mathrm{R}$} & \multirow[b]{2}{*}{$\begin{array}{c}\mathrm{R} \\
\text { Square }\end{array}$} & \multirow[b]{2}{*}{$\begin{array}{c}\text { Adjusted R } \\
\text { Square }\end{array}$} & \multirow[b]{2}{*}{$\begin{array}{l}\text { Std. Error } \\
\text { of the } \\
\text { Estimate }\end{array}$} & \multicolumn{5}{|c|}{ Change Statistics } \\
\hline & & & & & $\begin{array}{c}\text { R } \\
\text { Square } \\
\text { Change }\end{array}$ & $\begin{array}{c}\mathrm{F} \\
\text { Change }\end{array}$ & df1 & df2 & $\begin{array}{l}\text { Sig. F } \\
\text { Change }\end{array}$ \\
\hline 1 & $.848^{a}$ & .718 & .713 & 2.00591 & .718 & 122.497 & 1 & 48 & .000 \\
\hline
\end{tabular}

a. Predictors: (Constant), Kualitas Pelayanan

b. Dependent Variable: Kepuasan Pelanggan 
Kualitas layanan memberikan kontribusi yang relatif besar dan signifikan terhadap kepuasan pelanggan. ditunjukkan dengan perolehan parameter $\mathrm{Rxy}=0,845$ $(84,5 \%)$ dengan kontribusi $\mathrm{R}^{2}=0,718(71,8 \%)$.

\section{Coefficients ${ }^{\mathrm{a}}$}

\begin{tabular}{|c|c|c|c|c|c|}
\hline \multirow[b]{2}{*}{ Model } & \multicolumn{2}{|c|}{$\begin{array}{l}\text { Unstandardized } \\
\text { Coefficients }\end{array}$} & \multirow{2}{*}{\begin{tabular}{|l|}
$\begin{array}{l}\text { Standardized } \\
\text { Coefficients }\end{array}$ \\
Beta \\
\end{tabular}} & \multirow[b]{2}{*}{ 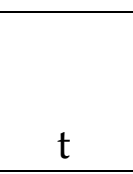 } & \multirow[b]{2}{*}{ Sig. } \\
\hline & B & Std. Error & & & \\
\hline \begin{tabular}{l|l}
1 & (Constant
\end{tabular} & $-1,117$ & 2,095 & &,- 533 &, 596 \\
\hline Kualitas I & ,283 & ,026 & , 848 & 11,068 & ,000 \\
\hline
\end{tabular}

a. Dependent Variable: Kepuasan Pelanggan

Persamaan regresi kualitas layanan terhadap kepuasan pelanggan dilihat dari nilai koefisien a sebesar $-1,12$ dan koefisien nilai B sebesar 0,283. Berdasarkan hal tersebut diperoleh model persamaan regresi linier $\bar{Y}=-1,12+0,28 \mathrm{X}$.

Berdasarkan analisis regresi linier sederhana menunjukkan bahwa terdapat pengaruh positif dan signifikan antara kualitas layanan terhadap kepuasan pelanggan. Hal tersebut ditunjukkan oleh persamaan regresi linier untuk kedua variabel dengan persamaan $\bar{Y}=-1,12+0,283 X$. Persamaan tersebut memberikan informasi bahwa penambahan satu skor kualitas layanan akan diikuti kenaikan 0,283 skor kepuasan pelanggan. Harga koefisien korelasi (r) sebesar 0,848 menunjukan hubungan yang sangat kuat, atau indeks determinasi sebesar 0,713 yang berarti bahwa $71,3 \%$ kualitas layanan mempengaruhi kepuasan pelanggan, selebihnya ditentukan oleh faktor lain

\section{d. Uji Hipotesis}

Kolom $t$ pada sebagaimana Tabel IV.44 digunakan pengujian $t$ untuk menguji kebenaran dari hipotesis dilakukan dengan cara membandingkan nilai t hitung yang telah diperoleh dengan nilai $t$ tabel dengan kriteria pengujian sebagai berikut:

1. jika thitung lebih besar dari tabel maka H0 ditolak dan Ha diterima

2. jika thitung kurang dari $t$ tabel maka $\mathrm{H} 0$ diterima dan Ha ditolak

Berdasarkan hal tersebut, pada kolom $\mathrm{t}$ (Tabel 4.44) diketahui bahwa nilai $\mathrm{t}$ hitung kualitas pelayanan sebesar 11,068. Dengan menggunakan tabel distribusi normal $\mathrm{t}$ menggunakan tingkat kepercauaan 95\% diperoleh nilai distribusi tabel $\mathrm{t}$ sebesar 2,011. Oleh karena t hitung > dari t tabel maka H0 ditolak dan Ha diterima.

Dari kurva uji hipotesis untuk variabel kualitas layanan dapat dilihat bahwa $t$ hitung 11,068 > nilai $\mathrm{t}$ tabel 2,011 dan berada pada daerah penolakan $\mathrm{H} 0$ atau penerimaan $\mathrm{Ha}$, ini menunjukkan bahwa adanya pengaruh yang signifikan kualitas pelayanan terhadap kepuasan pelanggan.

Kolom sig. digunakan untuk pengujian probabilitas. Kriteria pengujian adalah jika probabilitas $<0,05$ maka H0 ditolak dan Ha diterima. Berdasarkan nilai sig. pada tabel diketahui nilai probabilitas kualitas pelayanan sebesar 0,00. Nilai probabilitas tersebut menunjukkan bahwa $\mathrm{H} 0$ ditolak dan $\mathrm{Ha}$ diterima atau koefisien regresi regresi signifikan dengan kata lain kualitas pelayanan berpengaruh terhadap kepuasan pelanggan. 
ANOVA $^{b}$

\begin{tabular}{|c|c|c|c|c|c|c|}
\hline \multicolumn{2}{|c|}{ Model } & $\begin{array}{l}\text { Sum of } \\
\text { Squares }\end{array}$ & $\mathrm{df}$ & $\begin{array}{l}\text { Mean } \\
\text { Square }\end{array}$ & $\mathrm{F}$ & Sig. \\
\hline \multirow[t]{3}{*}{1} & Regression & 492.884 & 1 & 492.884 & 122.497 & $.000^{\mathrm{a}}$ \\
\hline & Residual & 193.136 & 48 & 4.024 & & \\
\hline & Total & 686.020 & 49 & & & \\
\hline
\end{tabular}

a. Predictors: (Constant), Kualitas

Pelayanan

b. Dependent Variable: Kepuasan Pelanggan

Pada tabel 4.45 dapat dilihat bahwa uji Anova F hitung untuk model 1 adalah 122,497 dengan tingkat signifikan $0,00<$ dari 0,05 dan juga $\mathrm{F}$ hitung $>\mathrm{F}$ tabel atau 122,49 > 2,78. Dengan demikian H0 ditolak dan Ha diterima artinya terdapat pengaruh hubungan linier antara variabel kualitas pelayanan dengan kepuasan pelanggan dan model regresi layak dan tepat untuk memprediksi kepuasan pelanggan.

Berdasarkan analisis data penelitian dengan argumen-argumennya sesuai perhitungan statistik maka penelitian menyimpulkan menolak $\mathrm{H} 0$ yang menyatakan tidak terdapat pengaruh positif dan signifikan antara kualitas layanan terhadap kepuasan pelanggan atau menerima Ha yang menyatakan terdapat pengaruh positif dan signifikan kualitas layanan terhadap kepuasan pelanggan

\section{KESIMPULAN}

Berdasarkan uraian dan analisis pada bab-bab sebelumnya, maka penelitian ini menyimpulkan sebagai berikut:

1. Secara umum, kualitas pelayanan jasa transportasi online Grab Car di wilayah kota Tangerang dalam kategori baik. Hal ini didapat dari analisis deskripsi terhadap item-item kuesioner yang berhubungan dengan kualitas pelayanan.

2. Secara umum, kepuasan pelanggan jasa transportasi online Grab Car di wilayah kota Tangerang dalam kategori baik. Hal ini didapat dari analisis deskripsi terhadap item-item kuesioner yang berhubungan dengan kepuasan pelanggan.

3. Korelasi (hubungan) antara kualitas pelayanan dengan kepuasan pelanggan jasa transportasi online Grab Car di wilayah kota Tangerang dalam kategori signifikan. Hal ini ditunjukkan dengan nilai koedisien korelasi sebesar 0,848 (korelasi yang kuat).

4. Berdasarkan dimensidimensinya kualitas pelayanan koefisien korelasi (r) Tangible dengan kepuasan sebesar 0,67, koefisien korelasi (r) Rekiability dengan kepuasan sebesar 0,72, koefisien korelasi (r) Responsiveness dengan kepuasan sebesar 0,57, koefisien korelasi (r) Assurance dengan kepuasan sebesar 0,836 dan koefisien korelasi antara Emhaty dengan kepuasan sebesar 0,841. Denga demikian terilhat bahwa korelasi yang palin tinggi terdapat pada dimensi Assurance dengan kepuasan pelanggan.

5. Pengaruh kualitas pelayanan terhadap kepuasan pelanggan jasa transportasi online Grab Car di wilayah kota Tangerang dalam kategori signifikan. Hal ini terlihat dari indeks determinasi sebesar 0,713 yang berarti 71,3\% kualitas 
layanan mempengaruhi kepuasan pelanggan, selebihnya ditentukan oleh faktor lain.

6. Hasil uji Hipotesis menunjukkan meolah $\mathrm{H} 0$ yang menyatakan tidak terdapat pengaruh positif dan signifikan antara kualitas pelayanan terhadap kepuasan pelanggan jasa transportasi online Grab Car di wilayah kota Tangerang, atau dengan kata lain menerima $\mathrm{H} 1$ yang menyatakan terdapat pengaruh positif dan signifikan antara kualitas pelayanan terhadap kepuasan pelanggan jasa transportasi online Grab Car di wilayah kota Tangerang.

\section{DAFTAR PUSTAKA}

Canming, Cao dan Chen Jianjun. An Empirical Analysis of the Relationship Among the Service Quality, Customer Satisfaction and Loyalty of High Speed Railway Based on Structural Equations Model. Journal of Canadian Social Science.

Ferdinand, Augusty (ed) dkk. 2017. Model Building in HRM \& Marketing Research; Summary of Finalizing Research Models. Lab Sains Pemasaran FE dan Bisnis UNDIP. Semarang.

Ferdinand, Augusty. 2014. Metode Penelitan Manajemen; Pedoman Penelitian untuk Penulisan Skripsi, tesis dan Disertasi Ilmu Manajemen. Edisi 5. UNDIP Press. Semarang.

Ghozali, Imam. 2016. Aplikasi Analisis Multivariete Dengan Program IBM SPSS 23. Cetakan VIII. UNDIP Press. Semarang.

Juga, Jari. Jouni Juntunen and Mari Juntunen. 2010. Impact of Service Quality, Image and Relational Aspect on Satisfaction and Loyalty in Logistic Outsourcing Relationship. Journal of Oulu Bussines School. Finland.

Karla, Eva. Analisis Pengaruh Kualitas Pelayanan Terhadap Kepuasan Konsumen Pada Matahari Dept. Store Kramat Jati, UG Jurnal Vol. 09 No. 9. Tahun 2015.

Kertajaya, Hermawan. 2006. Boosting Field Marketing Performance - From Startegy to Excecution. Kerjasama MarkPlus\&Co dan PT. Mizan Pustaka. Jakarta.

Khoirista, Afrinda. Edy Yulianto dan M. Kholid Mawardi. Pengaruh Kualitas Pelayanan Terhadap Kepuasan Pelanggan (Survey Pada Pelanggan Fedex Express Surabaya), Jurnal Administrasi Bisnis (Jab) Vol. 25 No. 2 Agustus 2015.

Lauw, Jessica dan Yohanes Sondang Kunto. Analisa Pengaruh Kualitas Layanan Terhadap Kepuasan Pelanggan Di The Light Cup Café Surabaya Town Square dan The Square Surabaya. Jurnal Manajemen Pemasaran Vo. 1 No. 12013.

Loke, Siew-Phaik, Ayankunle Adegbite Taiwo, Hanisah Mat Salim dan Alan G. Downe. Service Quality and Customer Satisfaction in a Telecommunication Service Provider. 2011. International Conference and Financial Management and Ecocomic. IPEDR Vol. 11 IACSIT Press. Sinagpore.

Mondy, R. Wayne and Joseph J. Martochio. 2016. Human Resource Management. Fourteenth Edition. Courier Kendallville, USA.

Munandar, Dadang. 2016. Relationship Marketing; Strtategi Menciptakan Keunggulan Bersaing. Ekuilibria. Yogyakarta.

Palero, Ariessa. Analisis Kualitas Jasa Day Trans Executive Shuttle Menggunakan Metode Importance Performance Analysis. e_Proceeding of Management. Vol 6 No. 1 April 2017. 
Punyani, Gazal. Ganesh Dash. Sorabh Sharma. An Assessment of Customers' e-Service Quality Perception Through Webqual Scale: A Study On Online Banking Services. Researchers World Journal of Arts, Scinece \& Commerce. Volum VI July 2015.

Rachmawaty, Ike Kusdyah. 2008. Manajemen Sumber daya Manusia. CV. Andi Offfset. Yogyakarta.

Rambat, Lupiyoadi. 2016. Manajemen Pemasaran Jasa Berbasis Kompetensi. Cetakan ke 3. Salemba Empat. Jakarta.

Rangkuti, Freddy. 2004. Flexible Marketing; Teknik agar Tetap Tumbuh dalam Situasi Bisnis yang Bergejolak E Analisis Kasus. PT. Gramedia Pustaka Utama. Jakarta.

Safira, Cindy Farah. Ari Kusyanti dan Himawat Aryadita, Analisis Kualitas Layanan Website Bukalapak Terhadap Kepuasan Pengguna Menggunakan E-S-QUAL, Jurnal Pengembangan Teknologi Informasi dan Ilmu Komputer Vol. 1, No. 12, Desember 2017.

Panjaitan, Januar Efendi dan Ai Lili Yuliati. Pengaruh Kualitas Pelayanan Terhadap Kepuasan Pelanggan Pada JNE Cabang Bandung. DeReMa Jurnal Manajemen Vol. 11 No. 2, September 2016.

Solimun. Adji Achmad Rinaldo Fernandes dan Nurjannah. 2017. Metode Statistika Multivariat; Pemodelan Persamaan Struktural (SEM) Pendekatan WarpPLS. Cetakan ke 2. UB Press. Malang.

Tjiptono, Fandy. 2017. Pemasaran Jasa; Prinsip, Penerapan, Penelitian. CV. Andi Offfset. Yogyakarta. 